\title{
The antiangiogenic phloroglucinol hyperforin inhibits the secretion of proMMP-2, proMMP-9 and VEGF-A during apoptosis of primary acute myeloid leukemia cells
}

\author{
Faten Merhi ${ }^{1,2}$, Ruoping Tang ${ }^{3,4}$, Ollivier Legrand ${ }^{3}$, Florence Nguyen-Khac ${ }^{1,5}$, Santos A. Susin ${ }^{1}$, Brigitte \\ Bauvois $^{1}$
}

${ }^{1}$ Centre de Recherche des Cordeliers, INSERM, Sorbonne Université, USPC, Université Paris Descartes, Université Paris Diderot, Paris F-75006, France.

${ }^{2}$ Department of Life \& Earth Sciences, Faculty of Sciences (I), Lebanese University, Beirut, Lebanon.

${ }^{3}$ Assistance Publique-Hôpitaux de Paris, Groupe Hospitalier Saint-Antoine, Service d'Hématologie Clinique, Paris F-75012, France.

${ }^{4}$ Service Génétique des Tumeurs, Département de Biologie et de Pathologie Médicale, Gustave Roussy Cancer Camus, Villejuif F94805, France.

${ }^{5}$ Assistance Publique-Hôpitaux de Paris, Groupe Hospitalier Pitié-Salpêtrière, Service d'Hématologie Biologique, Paris F-75013, France.

Correspondence to: Dr. Brigitte Bauvois, Centre de Recherche des Cordeliers, INSERM, Sorbonne Université, USPC, Université Paris Descartes, Université Paris Diderot, 15 rue de l'Ecole de Médecine, Paris F-75006, France.

E-mail: brigitte.bauvois@crc.jussieu.fr

How to cite this article: Merhi F, Tang R, Legrand O, Nguyen-Khac F, Susin SA, Bauvois B. The antiangiogenic phloroglucinol hyperforin inhibits the secretion of proMMP-2, proMMP-9 and VEGF-A during apoptosis of primary acute myeloid leukemia cells. J Cancer Metastasis Treat 2021;7:42. https://dx.doi.org/10.20517/2394-4722.2021.80

Received: 29 May 2021 First Decision: 28 Apr 2021 Revised: 30 Apr 2021 Accepted: 28 May 2021 First online: 28 May 2021

Academic Editor: Lucio Miele Copy Editor: Yue-Yue Zhang Production Editor: Yue-Yue Zhang

\section{Abstract}

Aim: Angiogenesis is observed in acute myeloid leukemia ( $A M L$ ). AML cells abnormally proliferate and are resistant to death. Positive regulators of angiogenesis, VEGF-A and matrix metalloproteinases (MMPs) 2 and 9 are markers of disease status in AML. The natural phloroglucinol hyperforin (HF) displays antitumoral properties of potential pharmacological interest. Herein, we investigated the effects of HF on MMP-2/9 and VEGF-A expression and survival of primary AML cells. 
Methods: Blood and bone marrow samples were collected in 45 patients with distinct subtypes defined by French American British classification, i.e., M0, M1, M2, M3, M4, and M5. Levels of MMPs and VEGF-A in leukemic blood cells and culture supernatants were determined by RT-PCR, ELISA, and gelatin zymography (MMPs). The balance between cell death and survival was assessed by flow cytometry with analysis of phosphatidylserine externalization and caspase-3 activation.

Results: The administration of HF promoted a caspase-associated apoptosis in primary AML blasts (from blood and bone marrow), but not normal blood cells and monocytes. In addition, HF inhibited the levels of secreted proMMP-2, proMMP-9, and VEGF-A without altering transcripts. The induction of apoptosis by HF significantly paralleled the inhibition of MMP-2/9 and VEGF-A release by HF. No differences were seen in response to the deleterious effects of HF between AML cells of distinct subtypes.

Conclusion: Our results suggest that HF, through its proapoptotic and potential antiangiogenic properties (by inhibiting MMP-2/9 and VEGF-A) on primary AML cells, might be a useful experimental agent, in combination with existing drugs, for new therapeutic approaches in the treatment of this incurable disease.

Keywords: Acute myeloid leukemia, apoptosis, hyperforin, matrix metalloproteinase, VEGF, secretion

\section{INTRODUCTION}

Angiogenesis, characterized by the formation of new vessels from preexisting blood vessels, participates in the progression of many malignant tumors by supplying oxygen and nutrients ${ }^{[1]}$. Angiogenesis induction is observed in several hematologic malignancies including acute myeloid leukemia ${ }^{[2-4]}$. Endothelial cells (ECs) and tumor cells secrete proangiogenic molecules ${ }^{[5,6]}$. Among the positive regulators of angiogenesis, vascular endothelial growth factors (VEGFs), and more specifically VEGF-A, play a prominent role to sustain angiogenesis $^{[1,5,6]}$. By binding to VEGF receptors at the surface of ECs, VEGF activates cell signaling pathways involved in the activation of the proliferation and survival of ECs $s^{[1,2,7]}$. In addition to VEGF, matrix metalloproteinases (MMPs) are regulators of pathologic angiogenesi $\mathrm{s}^{[8-10]}$. MMPs enable extravasation and migration of newly formed ECs and release VEGF bound to the extracellular matrix ${ }^{[8-11]}$. In particular, the proteolytic activities of MMP-2 and MMP-9 are implicated in tumor-associated processes such as cell growth, survival, migration, invasion, and angiogenesi ${ }^{[8,12,13]}$. Moreover, by binding cell surface proteins, the proforms of MMP-2 and MMP-9 can directly trigger intracellular signaling pathways involved in the modulation of cell growth and survival, migration, or angiogenesis ${ }^{[8,14]}$.

Of particular interest, some natural products display antiangiogenic effects and represent potential interest for the search of novel anti-cancer drugs ${ }^{[15-18]}$. Among these biologically active compounds, the phloroglucinol hyperforin (HF) isolated from the plant St John's wort (Hypericum perforatum, Figure 1) acts as a multi-targeting agent ${ }^{[15,19-21]}$. HF displays anti-depressant, antibacterial, antioxidant, and antiinflammatory properties ${ }^{[1,19-22]}$. Moreover, HF exhibits anti-proliferative and proapoptotic activities towards a number of mammalian cancer cell lines in vitro ${ }^{[15,23-28]}$. The antiangiogenic properties of HF have been demonstrated in vitro and in vivo ${ }^{[29,30]}$. HF's targets include MMP-2, MMP-9, and VEGF-A, all involved in cell survival and migration, and angiogenesis ${ }^{[31-33]}$.

Acute myeloid leukemia (AML) is a heterogeneous hematopoietic cancer characterized by the accumulation of malignant precursors of the myeloid lineage in the bone marrow (BM), interfering with the production of normal blood cells ${ }^{[34]}$. The latter are used to define distinct AML subfamilies ${ }^{[34]}$. Human AML cells show abnormally high levels of proliferation and survival, disseminating from bone marrow into peripheral blood and extramedullary organs ${ }^{[34]}$. The major cause of mortality of AML patients after allogeneic transplantation 


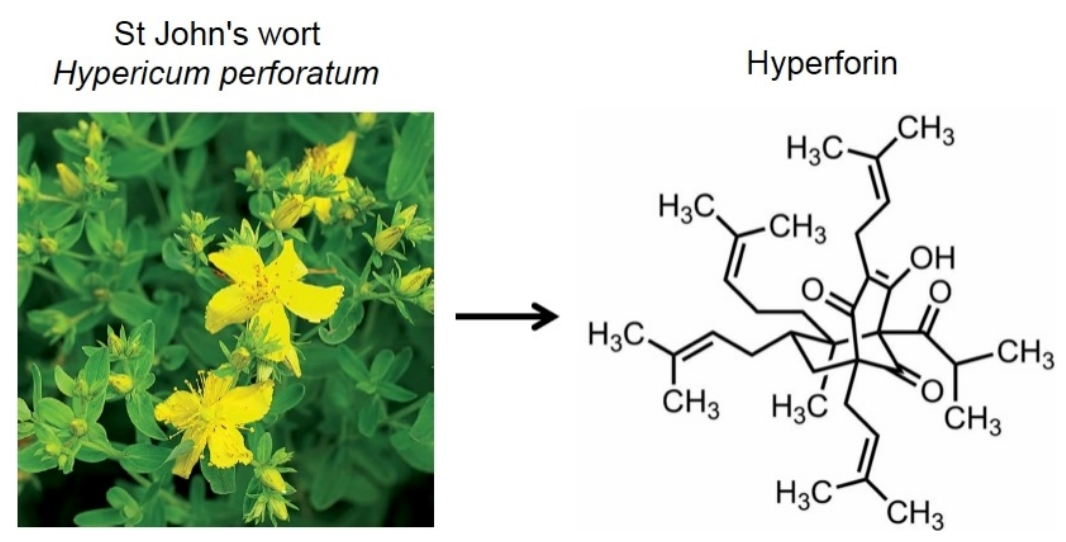

Figure 1. Hyperforin (HF) is a bio-active acylphloroglucinol abundantly present in the apical flowers of St John's wort (SJW) Hypericum perforatum L.SJW is a perennial flowering plant. HF is the primary active compound responsible for both the antidepressant and the anti-inflammatory properties of SJW. The chemical structure of $\mathrm{HF}$ is $\mathrm{C}_{35} \mathrm{H}_{52} \mathrm{O}_{4}(536 \mathrm{~g} / \mathrm{mol})$.

is graft-versus-host disease ${ }^{[4]}$. The conventional chemotherapeutic approach for AML patients is based on a treatment combining an anthracycline with cytarabine ${ }^{[35-37]}$. However, a majority of patients with AML are refractory to primary therapies or relapse later ${ }^{[35-37]}$. Both resistance and relapse are due to the heterogeneity of the disease, where high variability both among and within individual patients exist ${ }^{[35-37]}$. This underscores the need for alternative treatment options for AML patients, with increased tolerability and improved efficacy. Today, alternative strategies for the treatment of newly diagnosed AML patients include a new liposomal formulation of cytarabine and daunorubicin or the combination of venetoclax (a $\mathrm{BH} 3$ mimetic that inhibits the survival function of the B-cell lymphoma-2 anti-apoptotic protein) with hypomethylating agents or a low dose of cytarabine ${ }^{[36-38]}$. Unfortunately, these therapies are often still accompanied by adverse effects or favored mutations associated to drug resistance ${ }^{[36-38]}$. Therefore, novel therapies are needed to overcome resistance to these drugs, and the identification of new drugs in AML therapy is of great interest.

Increased BM angiogenesis in AML correlates with high levels of VEGF- ${ }^{[39,40]}$. BM blasts from patients with AML express and secrete VEGF- $\mathrm{A}^{[39-42]}$. The transcript and protein levels of VEGF-A are highly variable in circulating AML cells from pediatric patients ${ }^{[43]}$. The enhanced VEGF-A levels observed in plasma from AML patients might be explained as the expression of VEGF-A release from blood AML cells, and it appears to be associated with worse event-free survival and poor overall survival in $\mathrm{AML}^{[44]}$. In contrast to normal BM immature $\mathrm{CD} 34^{+}$progenitor cells, BM AML blasts express MMP-2 and MMP-9 transcripts and release detectable levels of MMP-2 and MMP-9 protein s $^{[4-47]}$. Similarly, blood AML cells express and secrete MMP2 and MMP- ${ }^{[48]}$. To the best of our knowledge, there are no literature data reporting the co-expression of $V E G F-A$ and $M M P-2 / 9$ in circulating AML blasts. In this study, we first analyzed the expression status of these factors in myeloid blasts from peripheral blood as a function of the latter's French-American-British (FAB) subtype (Mo, M1, M2, M3, M4, and M5). In addition, we investigated the ability of HF to exhibit anti-cancer activity in AML disease through the modulation of AML cell survival process and secretion of MMP-2/9 and VEGF-A. Understanding HF's anti-leukemic activity in AML may provide a new model for the treatment of this disease.

\section{METHODS}

\section{Patients, AML samples, and cell cultures}

Peripheral blood was collected from 45 patients with AML according to standard clinical criteria and the FAB Committee's cytological criteria $\left(\geq 80 \% \text { peripheral blood AML blasts } \mathrm{CD} 33^{+} \mathrm{CD} 13^{+}\right)^{[49]}$. The biological and clinical characteristics of AML patients are listed in Table 1. Bone marrow (BM) samples were collected 
Table 1. Clinical characteristics of patients with AML

\begin{tabular}{ll}
\hline Characteristic & No. (\%) \\
\hline Total & $45(100)$ \\
Age, years & \\
Median (range) & $60[19-81]$ \\
Male & $24(53)$ \\
FAB subfamily & \\
M0 & $3(7)$ \\
M1 & $14(31)$ \\
M2 & $11(24)$ \\
M3 & $1(2)$ \\
M4 & $7(14)$ \\
M5 (including 2 M5b*) & $9(20)$ \\
\hline
\end{tabular}

Two AML patients (MO and M4) were in relapse at the time of our analysis and responded to the effects of HF. FAB: French-American-British; M0: undifferentiated blast; M1: undifferentiated myeloblast; M2: myeloblast; M3: promyelocyte; M4: myelomonocyte; M5: monoblast; M5b*: monoblast with differentiation.

at the time of diagnosis from three AML patients. Control blood samples were collected from healthy, fully anonymized donors. Peripheral blood mononuclear cells (PBMCs) were isolated after Ficoll separation. More than $80 \%$ of AML PBMCs were $\mathrm{CD} 33^{+} \mathrm{CD}_{13} 3^{+}$. Monocytes were isolated from normal PBMCs by adherence as described ${ }^{[50]}$. More than $95 \%$ of monocytes were CD $14^{+}$.

Freshly isolated cells $\left(10^{6} / \mathrm{mL}\right)$ were cultured in RPMI 1640 medium (Life Technologies, Paisley, UK) supplemented with $10 \%$ heat-inactivated fetal calf serum (FCS) (Gibco; lipopolysaccharide levels < $0.1 \mathrm{ng} / \mathrm{mL}$ ), $2 \mu \mathrm{M}$ L-glutamine, $1 \mu \mathrm{M}$ sodium pyruvate, and $40 \mu \mathrm{g} / \mathrm{mL}$ gentamicin, in a $5 \% \mathrm{CO}_{2}$ humidified atmosphere at $37^{\circ} \mathrm{C}$. The cells were then treated with purified hyperforin $(1.4,2$, and $3 \mu \mathrm{g} / \mathrm{mL}$, corresponding to 2.5, 3.6 and $5.4 \mu \mathrm{M}$, respectively) (Cayman Chemical Company, Ann Arbor, Michigan, USA) for 24-72 h. In negative control experiments with HF, cells were treated with the same volume of $\mathrm{MeOH}$ alone. After incubation, the cells were collected, washed once, and then used for flow cytometry assays and RT-PCR analyses. The culture supernatants from AML blood cells were harvested under sterile conditions and frozen before MMP-2, MMP-9, and VEGF-A contents were determined by ELISA and zymography. Cell morphology was assessed as previously described ${ }^{[51]}$.

\section{Flow cytometry}

Intact cells were directly immunostained as previously described ${ }^{[52]}$. The balance between cell apoptosis and survival was assessed using the annexin V-FITC/propidium iodide (PI) cell death detection kit (BeckmanCoulter, Les Ullis, France). Intracellular active caspase-3 was detected in permeabilized cells as described in $^{[53]}$. Stained cells were analyzed with a Coulter Epics XL flow (Beckman-Coulter, Les Ullis, France) cytometer. Data were analyzed using LYSYS (Beckman-Coulter) software.

\section{Reverse transcriptase PCR assays}

RNA extraction from treated cells and cDNA synthesis were performed as described previously ${ }^{[52]}$. The cDNAs coding for human MMP-2, MMP-9, VEGF-A, and $\beta 2$-microglobulin were amplified in PCRs, using primers synthesized by Sigma-Proligo according to the published sequences ${ }^{[2,54,55]}$. The PCR products were visualized as described previously ${ }^{[56]}$. 


\section{Measurement of MMP-2/9 gelatinolytic activity by zymography}

Analysis of MMP-2/9 activities in culture supernatants was carried out in 7.5\% (w/v) SDS-polyacrylamide gels containing $0.1 \%$ gelatin $(\mathrm{w} / \mathrm{v})$, as described $\mathrm{in}^{[52]}$. Gelatinolytic activities of MMPs were detected as transparent bands on the background of Eza-blue stained gelatin. The bands were acquired in a densitometer (Oncor).

\section{ELISA analysis}

Total MMP-2 (pro and active forms), total MMP-9 (pro and active forms), and VEGF-A (containing 125 amino acid residues, $\mathrm{VEGF}_{125}$ ) contents in culture supernatants were determined using commercial ELISA kits provided by R\&D (Abingdon, UK). Controls included culture medium alone incubated under the same conditions. Detection levels for MMP-2/9 was $1 \mathrm{ng} / \mathrm{mL}$ and for VEGF-A $5 \mathrm{pg} / \mathrm{mL}$.

\section{Statistics}

Statistical analyses were performed using GraphPad Prism software (version 7.0, GraphPad Software, La Jolla, CA, USA). Groups were compared using Mann-Whitney tests or unpaired or paired Student's $t$-tests. Correlations between variables were tested by calculating Spearman's coefficient $(\mathrm{r})$ and the $P$-value $\leq 0.05$ was considered statistically significant. All tests were two-tailed for greater stringency.

\section{RESULTS}

\section{Expression of proMMP-2, proMMP-9, and VEGF-A in primary AML cells}

We first examined the levels of transcripts of MMP-2/9 and VEGF-A in leukemic blood cells from 15 AML patients with different FAB subtypes Mo, M1, M2, M4, and M5 (FAB M3 is not represented because of its low frequency in the cohort). Representative examples of PCR products are shown in Figure 2A. The PCR products for MMP-2/9 and VEGF-A were detected at various degrees in all AML samples tested (Figure 2A and data not shown). MMP-2 and VEGF-A transcripts were detected in all tested samples, whereas MMP-9 transcript was detected in 12 of the 15 tested samples (Figure $2 \mathrm{~A}$ and data not shown). The transcripts patterns showed no associations with the FAB subtype (Figure $2 \mathrm{~A}$ and data not shown). As exemplified in Figure $2 \mathrm{~B}$, zymography analysis of the supernatants of AML cells ( $72 \mathrm{~h}$ of culture) showed the presence of proMMP-9 and proMMP-2 proteins at 92 and $72 \mathrm{kDa}$, respectively [Figure $2 \mathrm{~B}$ ], whereas the active forms of MMP-9 (at $82 \mathrm{kDa}$ ) and MMP-2 (at $65 \mathrm{kDa}$ ) were not detected [Figure 2B]. In some cases, an intermediate $\simeq 85 \mathrm{kDa}$ MMP-9 form was seen [Figure $2 \mathrm{~B}$ ]. The release of these proteins by primary AML cells in vitro and under basal conditions was quantified in ELISAs: the mean (range) of total MMP-2, total MMP-9, and VEGF-A concentrations (after a $72 \mathrm{~h}$ of culture) released by AML cells were, respectively, $4.44 \mathrm{ng} / \mathrm{mL}$ $(1-13 \mathrm{ng} / \mathrm{mL})$ for $10^{6}$ cells, $16.04 \mathrm{ng} / \mathrm{mL}(1-51 \mathrm{ng} / \mathrm{mL})$ for $10^{6}$ cells and $57.71 \mathrm{pg} / \mathrm{mL}(5-288 \mathrm{pg} / \mathrm{mL})$ for $10^{6}$ cells [Figure $2 \mathrm{C}$ ] and were not correlated with the FAB subtype $(P>0.05)$. Next, we tested for associations between the levels of released MMP-2, MMP-9, and VEGF-A. No correlations were found for MMP-2 and MMP-9 $(r=0.2859, P=0.1483)$, MMP-2 and VEGF-A $(r=0.1046, P=0.6867)$, or MMP-9 and VEGF-A $(r=$ $0.1817, P=0.4811)$ [Figure 2D].

\section{HF induces apoptosis in primary AML cells independently of the FAB subtype}

We assessed the effects of HF on the viability of blood PBMCs obtained from 37 AML patients. Cell death was assessed by determining phosphatidylserine exposure at the cell surface (using annexin-V-FITC binding) and cell membrane disruption (using propidium iodide labeling). Initial studies showed that HF's optimal effects in inducing death of AML cells occurred in a time-dependent manner (24-72 h). Consequently, the lethal effect of $\mathrm{HF}$ at $72 \mathrm{~h}$ was investigated in all subsequent experiments. As exemplified in Figure $3 \mathrm{~A}$, the proportion of total annexin- $\mathrm{V}^{+}$cells (dead cells) by $72 \mathrm{~h}$ enhanced after treatment with increasing doses of $\mathrm{HF}(1.4,2$, and $3 \mu \mathrm{g} / \mathrm{mL})$ compared to control (untreated) experiments. Accordingly, light microscopy observations revealed that AML cell treatment with HF led to a deterioration of the cell 
A

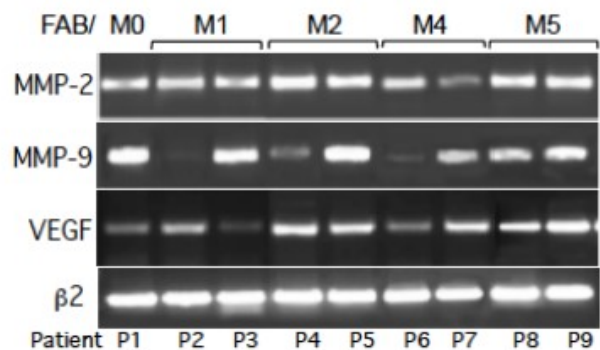

B

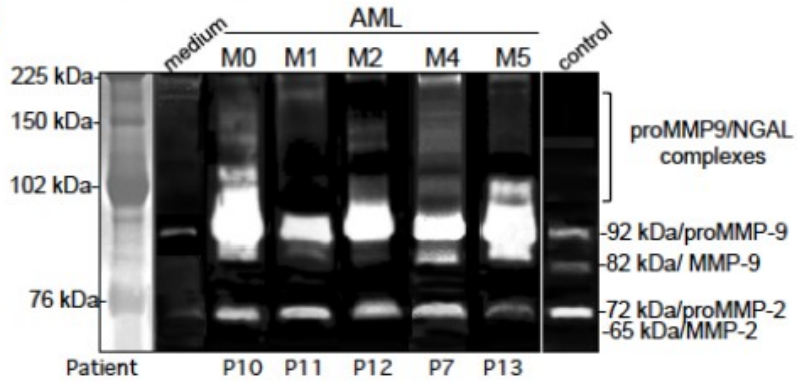

C
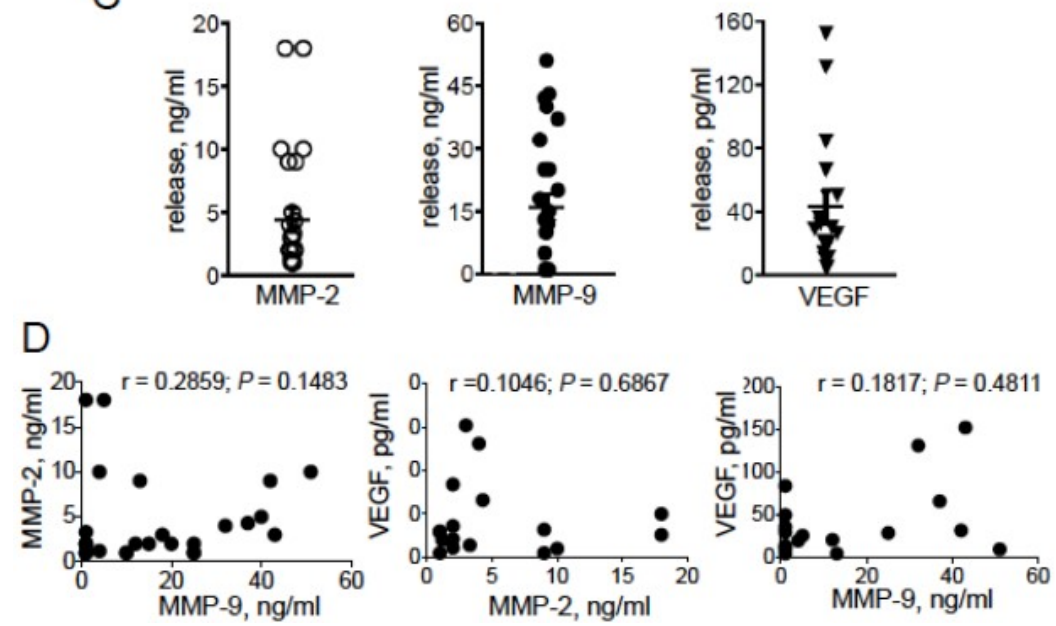

Figure 2. Expression of MMP-2, MMP-9, and VEGF-A in primary AML cells. (A) PCR analyses of MMP-2/9 and VEGF-A transcripts. Samples were standardized for total cDNA content by assessing the presence of identical amounts of $\beta 2$-microglobulin transcripts. (B) Expression profiles of MMP-2/9 (pro and active forms) were analyzed by zymography using $7.5 \%(\mathrm{~W} / \mathrm{v}$ ) SDS-polyacrylamide gels containing $0.1 \%$ gelatin $(\mathrm{w} / \mathrm{v}$ ) in the 72 -h conditioned media (supernatant) from AML cells. The control medium was an FCSsupplemented culture medium alone incubated under the same conditions; the culture supernatant from U937 (M5) cells was used as a positive control for proMMP-2/9 and active MMP-9 proteins. The assay's sensitivity for MMP-2/9 gelatinolytic activity was $25 \mathrm{ng} / \mathrm{mL}$. (C) Total MMP-2 (first column, $n=27$ samples), total MMP-9 (second column, $n=27$ samples), and VEGF-A (third column, $n=17$ samples) productions in the 72 -h culture supernatants from AML cells were determined by ELISA. Mean concentrations \pm SEM are indicated. Spots are superposed in all columns. (D) Correlations among MMP-2, MMP-9, and VEGF-A levels in the 72-h culture supernatants from AML cells. Spearman's correlation coefficient $(r)$ and the $P$-value are shown for MMP-2 vs. MMP-9 $(n=27)$, MMP-2 vs. VEGF-A $(n=17)$, and MMP-9 vs. VEGF-A $(n=17)$

morphology, with a decrease in the nuclear/cytoplasmic ratio at $1.4 \mu \mathrm{g} / \mathrm{mL} \mathrm{HF}$, an apparition of an enlarged cytoplasm at $2 \mu \mathrm{g} / \mathrm{mL} \mathrm{HF}$, and appearance of shrunken cells at $3 \mu \mathrm{g} / \mathrm{mL} \mathrm{HF}$, in a manner indicative of a typical apoptotic morphology [Figure $3 \mathrm{~B}$ ]. In contrast, and as previously reported for normal $\mathrm{PBMCs}^{[24]}, \mathrm{HF}$ $(2 \mu \mathrm{g} / \mathrm{mL}, 72 \mathrm{~h})$ showed no marked toxic effects on normal PBMCs and isolated monocytes [Figure $3 \mathrm{C}$ ]. As exemplified in Figure 3D, HF-mediated cell death similarly increased in blood cells and BM cells from the same patient with AML. In summary, the effects of HF $(2 \mu \mathrm{g} / \mathrm{mL}, 72 \mathrm{~h})$ were assessed on the viability of 37 AML samples with Mo, M1, M2, M3, M4, and M5 FABs. Two samples, from M1 and M4 patients, 
A AML-P5

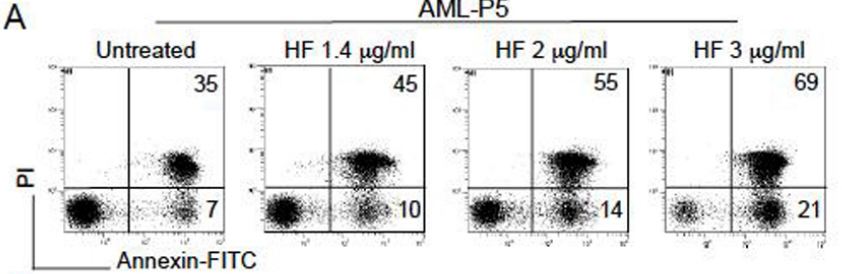

B

AML-P10

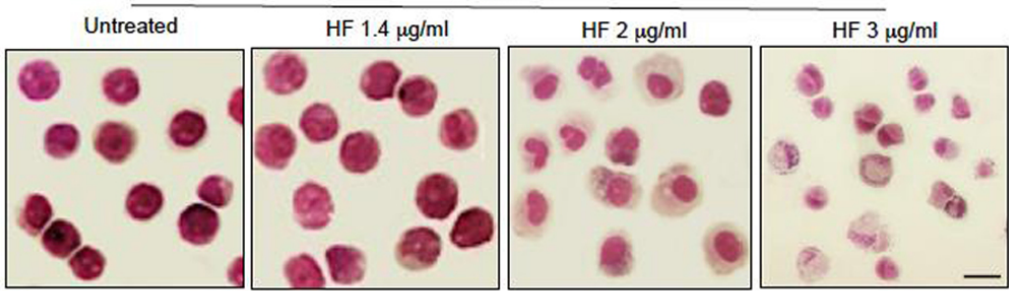

C

Normal PBMC

Normal monocytes

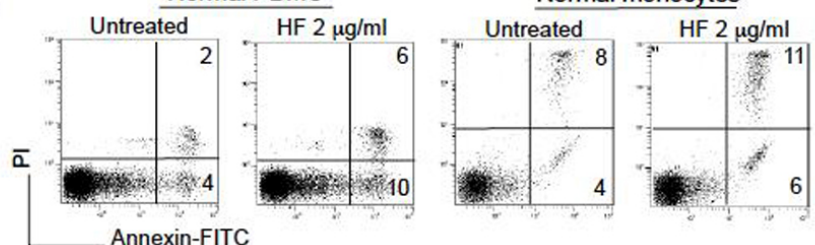

AML-P14

D

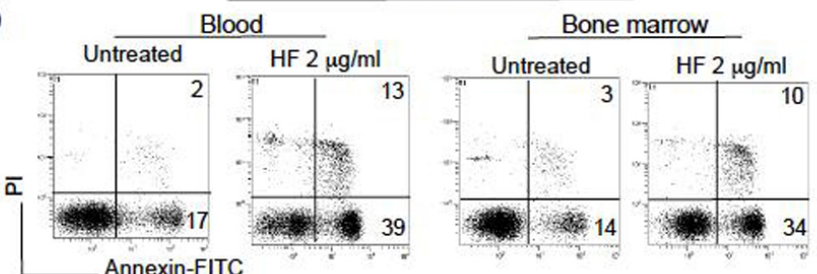

E

$\mathrm{F}$
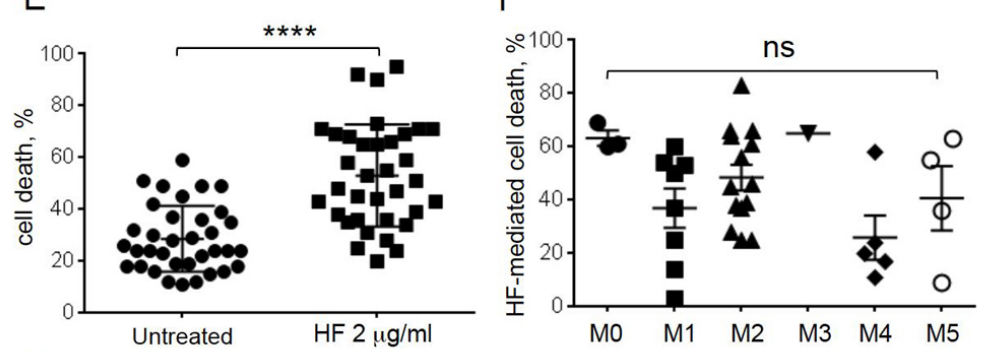

G

Responder AML-P23
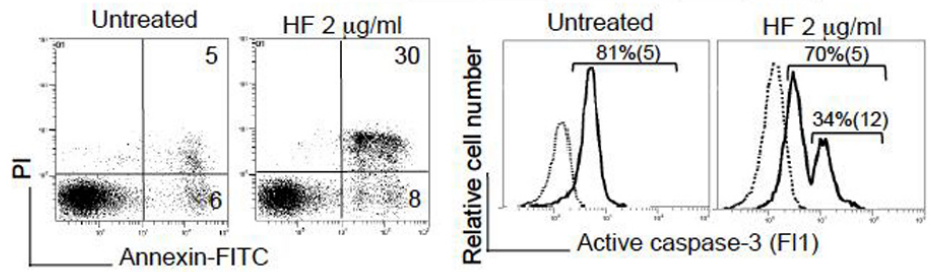

$\mathrm{H}$

Non responder AML-P21
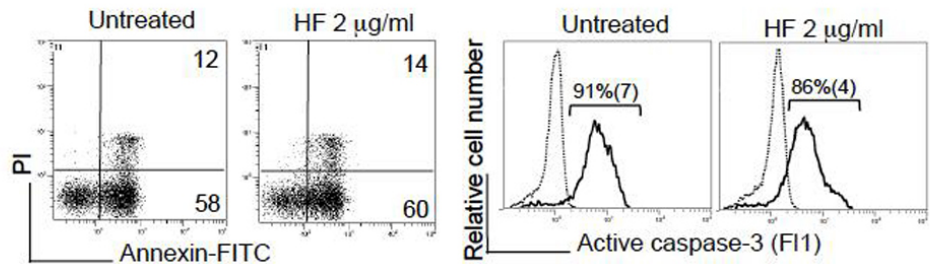
Figure 3. $\mathrm{HF}$ induces resistance to apoptosis in AML cells. (A) Representative cytograms of AML blood cells treated for $72 \mathrm{~h}$ with $\mathrm{HF}$ $(1.4,2$, and $3 \mu \mathrm{g} / \mathrm{mL})$; detection of dead cells after annexin-V-FITC/PI staining and flow cytometry. The percentage of annexin- $V$ positive cells is shown. (B) Light microscopy of non-treated and AML cells treated with HF: original magnification, 600x; MayGrünwald stain; Scale bar, $10 \mu \mathrm{m}$. (C) Representative cytograms of PBMCs and isolated monocytes from two healthy donors, treated with $2 \mu \mathrm{g} / \mathrm{mL} \mathrm{HF}$ for $72 \mathrm{~h}$, and cell death was assessed as described in (A). (D) Representative cytograms of AML cells isolated from blood and bone marrow of one AML patient, treated with $2 \mu \mathrm{g} / \mathrm{mL} \mathrm{HF} \mathrm{for} 72 \mathrm{~h}$, and cell death was assessed as described in (A). (E) Cell death levels $(2 \mu \mathrm{g} / \mathrm{mL}, 72 \mathrm{~h}$ ) were determined in untreated and HF-treated malignant cells from $35 \mathrm{AML}$ patients. Mean concentrations $\pm \mathrm{SD}$ are indicated; $P$ value was calculated using a Mann-Whitney U-test; ${ }^{* \star \star \star} P<0.0001$. (F) The percentage of HF-mediated AML cell death was determined for all FAB subtypes by subtracting the percentage of annexin-V-positive cells in the absence of HF from the percentage of annexin-positive cells in the presence of $\mathrm{HF}$, and then dividing by the percentage of annexin-positive cells in the presence of $\mathrm{HF} \times 100$. Data are the mean $\pm \operatorname{SEM}(M 0, n=3 ; M 1, n=8 ; M 2, n=14 ; M 3, n=1 ; M 4, n=5 ;$ and M5, $n=4)$. $P$ values were calculated using one-way ANOVA (without M3 value); ns: not significant. (G\&H) AML cells were treated with HF ( $2 \mu \mathrm{g} / \mathrm{mL}, 72 \mathrm{~h})$ and the percentage of annexin- $\mathrm{V}$-positive cells was determined as described in (A) (left). In parallel, active caspase-3 expression was measured by flow cytometry (right); cells were stained with FITC-rabbit Ig (control, dashed line) or anti-active caspase-3-FITC (solid line); the percentages refer to the percentage of active caspase-3. (G) Responder AML cells are sensitive to HF treatment with death induction (38\% vs. $11 \%$ for untreated) and caspase-3 activation (34\%). (H) Non-responder AML cells do not respond to HF treatment (no cell death and no caspase-3 activation).

respectively, exhibited high levels of basal death (> 70\% annexin-V-positive cells) and did not respond to HF treatment [see Figure $3 \mathrm{H}$ (left) for M4 patient]. For the other 35 samples, cultured leukemic cells exhibited variable baseline levels of spontaneous death [Figure 3E]. Exposure to HF increased death in 33 of the 35 blood samples [Figure 3E]. The paired- $t$ test confirmed the significant enhanced death in HF-treated AML cells [Figure $3 \mathrm{E}]$. The lethal effect of HF was found independent of the FAB subtype $(P=0.0735)$ [Figure $3 \mathrm{~F}$ ]. These data collectively indicate that HF induces apoptosis in cultured AML cells independently of FAB status.

We previously showed that HF induced caspase-dependent apoptosis in AML cell lines representative of primary AML cells through the mitochondrial (intrinsic) pathway ${ }^{[26]}$. Caspase- 3 is the executioner caspase of intrinsic apoptosis ${ }^{[57]}$. To confirm the caspase pathway's involvement in HF-induced apoptosis of primary AML cells, we investigated the level of active caspase-3 expression in two AML samples that, respectively, responded [Figure $3 \mathrm{G}$ ] or not [Figure $3 \mathrm{H}$ ] to the lethal action of HF. As expected, AML responder cells displayed higher levels of active caspase-3 than untreated cells [Figure $3 \mathrm{G}$ ]; in contrast, the levels of active caspase-3 did not change in non-responder AML cells [Figure $3 \mathrm{H}$ ]. Altogether, these results indicate that HF induces caspase-associated apoptosis in primary AML cells, independently of the FAB subtype.

\section{HF inhibits the secretion of proMMP-2/9 and VEGF-A in primary AML cells}

We assessed the ability of HF $(2 \mu \mathrm{g} / \mathrm{mL}, 72 \mathrm{~h})$ to modulate the spontaneous release of MMP-2, MMP-9, and VEGF-A by primary AML cells. ELISA data show that HF did not affect the basal levels of MMP-2/9 $\leq$ $1 \mathrm{ng} / \mathrm{mL}$ and VEGF-A $\leq 5 \mathrm{pg} / \mathrm{mL}$. In contrast, in the group of AML samples with detectable concentrations of MMP-2/9 (> $1 \mathrm{ng} / \mathrm{mL})$ and VEGF-A $(>5 \mathrm{pg} / \mathrm{mL})$, the levels of proteins release fell after treatment with HF [Figure $4 \mathrm{~A}$ ]. This decrease appeared to be independent of FAB subtype $(P>0.05)$. The Mann-Whitney test confirmed the significant downregulation of the release of MMP-2/9 and VEGF-A by HF-responsive AML cells [Figure 4A]. Decrease of MMP-9 levels by HF was associated with reduced gelatinolytic activity of the $92 \mathrm{kDa}$ form of proMMP-9 accompanied by the accumulation of the truncated $85 \mathrm{kDa}$ form independently of the FAB subtype tested (Figure $4 \mathrm{~B}$ and data not shown); the increased amounts of $85 \mathrm{kDa}$ form seemed to be inversely associated with the amounts of the $92 \mathrm{kDa}$ form in HF-treated AML samples. PCR reactions indicated that HF did not markedly affect the transcription levels of MMP-2/9 and VEGF-A (when normalized to $\beta 2$-microglobulin levels) in representative AML samples from distinct FAB subtypes [Figure $4 \mathrm{C}$ ]. Altogether, these experiments strongly suggest that HF inhibits, in a post-transcriptional manner, MMP-2/9 and VEGF-A production in AML cells. Furthermore, the correlations between the levels of released proteins on the one hand and cell death on the other hand were evaluated in samples from both 

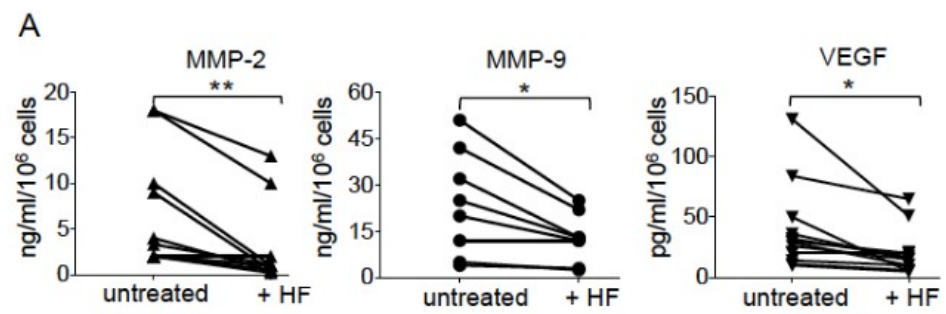

B

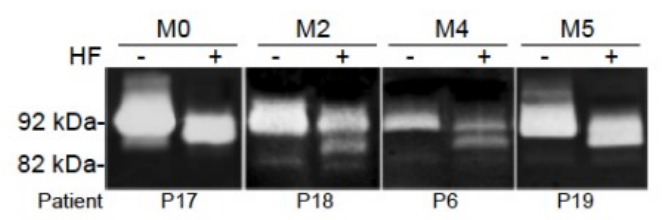

C
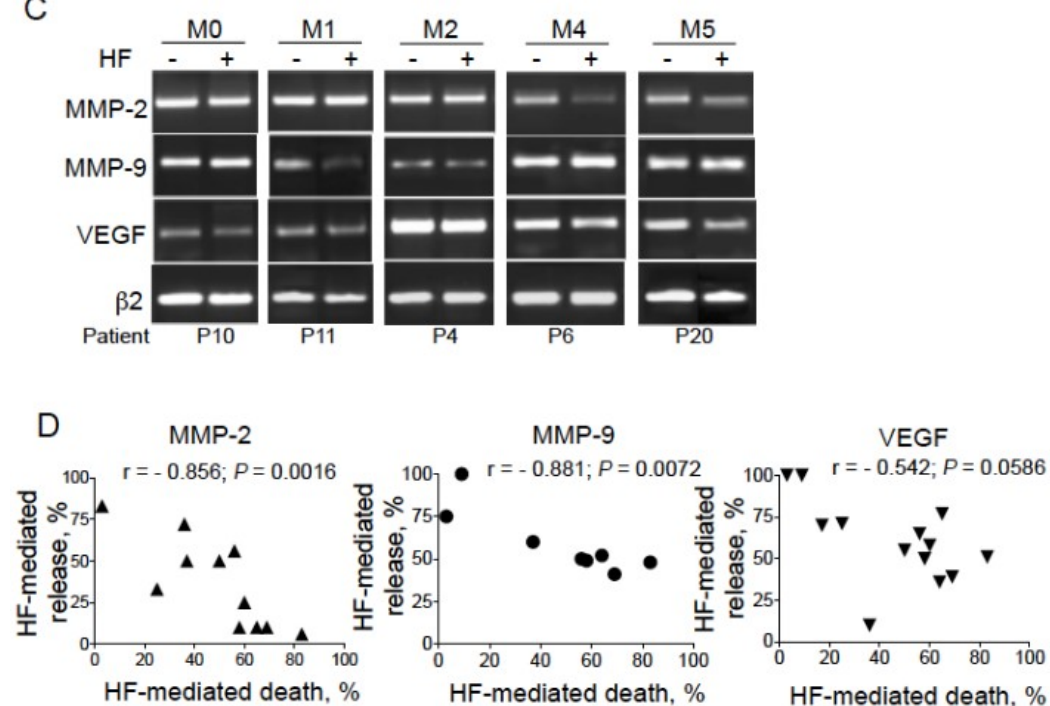

Figure 4. HF inhibits the production of proMMP-2/9 and VEGF-A by AML cells. (A) Total MMP-2 $(n=11)$, total MMP-9 $(n=8)$, and VEGF-A $(n=13)$ productions in the 72 -h culture supernatants from AML samples untreated or treated with HF $(2 \mu \mathrm{g} / \mathrm{mL})$ were determined by ELISA. $P$ value was calculated using a Mann-Whitney $U$-test; ${ }^{\star} P<0.05 ;{ }^{\star}{ }^{\star} P<0.01$. (B) The gelatinolytic activities of MMP-2/9 were analyzed using zymography (see Figure 2) in the supernatants from four AML cell samples treated or not with HF $(2 \mu \mathrm{g} / \mathrm{mL}, 72 \mathrm{~h})$. (C) PCR analyses of MMP-2, MMP-9, VEGF-A, and $\beta 2$-microglobulin transcripts from 5 AML samples treated or not with $\mathrm{HF}(2 \mu \mathrm{g} / \mathrm{mL}, 24 \mathrm{~h})$. (D) Correlations between the levels of HF-mediated release of MMP-2/9 or VEGF-A and HF-mediated death in AML cells ( $n=11$ for MMP-2; $n=8$ for MMP-9; and $n=13$ for VEGF-A). The percentage of HF-mediated AML cell death was determined as described in Figure 3. The percentage of HF-mediated release was determined by subtracting the percentage of MMP/VEGF-A release in the absence of HF from the percentage of MMP/VEGF-A release in the presence of HF, and then dividing by the percentage of MMP/VEGF-A release in the absence of HF $\times 100$. Spearman's correlation coefficient $(r)$ and the $P$-value are shown.

the untreated AML group and the HF-treated group. The levels of released MMP-2/9 and VEGF-A were not correlated with basal apoptosis in the group of unstimulated AML cells $(P>0.05)$. In contrast, we identified in the group of HF-treated AML cells a negative correlation between HF-mediated proteins' release and HF-mediated apoptosis [Figure 4D]. HF-mediated AML cell death was significantly (negatively) correlated with the release of MMP-2 $(r=-0.856, P=0.0016)$ and MMP-9 $(r=-0.881, P=0.0072)$ but not with that of VEGF-A $(r=-0.542, P=0.0588)$ [Figure $4 \mathrm{D}$ ]. These results indicate that HF induces the release of MMP-2/9 and VEGF-A in AML cells. 


\section{DISCUSSION}

Enhanced angiogenesis participates in the progression of AML, and pharmacological targeting of proangiogenic proteins (including MMPs and VEGF-A) might be a possible antileukemic strategy. HF exhibits antiangiogenic and proapoptotic activities towards various cancer cells ${ }^{[15,19,29,30]}$. AML cells abnormally proliferate and escape apoptosis. Our present study provides evidence that primary blood AML cells coexpress proMMP-2, proMMP-9, and VEGF-A proteins. The major finding of our study indicates that HF is able to inhibit two biological events related to AML progression and angiogenesis, i.e., survival and secretion of MMP-2/9 and VEGF-A in AML patients' cells.

Peripheral blood blasts from AML patients express detectable levels (transcript and secreted protein) of MMP-2, MMP-9, and VEGF-A. As previously reported for BM AML blasts ${ }^{[45]}$, circulating AML cells release the proforms of MMP-2 (72 kDa) and MMP-9 $(92 \mathrm{kDa})$ proteins. An additional $85 \mathrm{kDa}$ form of MMP-9 is observed in some AML samples (independently of the FAB subtype). A previous study reported that BM AML blasts with the subtypes M4/M5 express an $\simeq 85 \mathrm{kDa}$ MMP-9 at their cell surface ${ }^{[58]}$. Breast cancer cells express an $85-\mathrm{kDa}$ MMP-9 devoid of complex carbohydrates, which might result from deglycosylation ${ }^{[59]}$. Interestingly, active MMP-3 and active MMP-13 can cleave proMMP-9 to generate an 86-kDa intermediate ${ }^{[60,61]}$. The origin of this MMP-9 variant and its role in AML remain to be defined.

We observed no intercorrelations among the levels of MMP-2, MMP-9, and VEGF-A secreted by AML cells, likely reflecting their variable expression both among and within individual AML cells. MMP-2 transcription is mainly regulated by signal transducer and activator of transcription 3 (STAT3) ${ }^{[62,63]}$, whereas MMP-9 transcription is regulated via NF- $\mathrm{kB}, \mathrm{AP}-1$, and SP-1 ${ }^{[64]}$. VEGF transcription can be regulated by STAT3 and $\mathrm{HIF}^{[2,63,65]}$. Our data strongly suggest that the heterogeneity found in the release profiles of MMP-2/9 and VEGF-A proteins may be related to the distinct gene regulations of MMP-2/9 and VEGF in AML cells. Moreover, the released levels of MMP-2/9 and VEGF-A do not appear to depend on the differentiation stage of AML cells. Our data agree with studies in which the levels of MMP-2 (plasma), MMP-9 (BM), or VEGF-A (BM) and FAB subtypes are not associated ${ }^{[39,40,45,46,66]}$. In contrast, other studies have shown an association between MMP-9 or VEGF-A (BM) and AML-M4/M5 $5^{[43,46]}$, as well as between VEGF-A (BM) and AML-Mo ${ }^{[42]}$. Larger studies are mandatory to fully address this question.

We previously showed that HF exhibits proapoptotic activities in AML cell lines of distinct FAB phenotype $^{[26]}$. In particular, HF did not activate the enzymatic activities of caspase-3/8/9 directly (B. Bauvois, unpublished results) but promoted caspase-mediated apoptosis involving BAD and Noxa activation in AML U937 (M5) cells ${ }^{[26]}$. BAD is a direct downstream target of Akt ${ }^{[67]}$. We previously presented the first evidence that HF, by directly inhibiting Akt-1 kinase activity, prevents BAD phosphorylation, which in turn activates its proapoptotic role in U937 cells ${ }^{[26]}$. Primary AML cells overexpress Akt ${ }^{[67]}$. Activated Akt signaling protects AML cells from apoptosis ${ }^{[67]}$. In this study, the proapoptotic effect of HF in AML cell lines is confirmed in primary AML cells, independently of the latter's FAB subtype; HF-mediated AML cell death occurred in 33 of the 35 AML samples tested, accompanied by caspase- 3 activation. Whether HF activates the proapoptotic function of BAD through Akt1 inhibition in primary cells remains to be confirmed. HF exerts selective cytotoxicity on AML cells but not on normal PBMCs and monocytes. Importantly, BM AML cells appear as sensitive as circulating AML cells toward the apoptotic effect of HF, suggesting that HF might be of interest for the therapy of AML through its potential capacity to eradicate BM leukemic stem cells. Moreover, the induction of apoptosis by $2 \mu \mathrm{g} / \mathrm{mL}$ of HF parallels the inhibition of secretion of MMP2/9 and VEGF-A by HF at the same concentration. Suppression of released MMP-2/9 and VEGF-A proteins by HF does not appear correlated with their transcript levels, suggesting a post-transcriptional inhibition. Our observations strongly suggest that HF induces simultaneously: (1) suppression of MMP-2/9 and VEGF- 
A production; and (2) apoptosis in primary AML cells. However, to what extent are apoptosis and secretion interdependent or related? A previous study showed that the stable dicyclohexylammonium salt of HF (HFDCHA, $0.5 \mu \mathrm{M}$ ) inhibits MMP-2 release by two human epithelial cell lines (HT-1080 and SK-N-BE), while apoptosis in these cells is induced at concentration 16 -fold higher (IC $\geq 8 \mu \mathrm{M})$, suggesting that HF-DCHA induces two separate events in these tumor models ${ }^{[68]}$. The effect of $\mathrm{HF}$ at $\leq 2 \mu \mathrm{g} / \mathrm{mL}$ on MMP-2/9 and VEGF-A release remains to be assessed in AML cells. Furthermore, the decreased production of these hemoregulators might result from the apoptotic process. Conversely, the inhibition of MMP-2/9 and VEGF-A might impact the survival of AML cells. Indeed, VEGF-A signaling (via PI3K/Akt activation) favors autocrine AML cell proliferation, survival, and chemotherapy resistance ${ }^{[6,70]}$. Moreover, proMMP-2 and proMMP-9 have the ability to directly activate signaling pathways modulating cell survival, migration, and angiogenesis ${ }^{[8]}$. For example, the binding of proMMP-9 to its docking receptors $\alpha 4 \beta 1$ integrin and CD44 induces an intracellular signaling pathway (STAT3/Lyn/Mcl-1) that favors the survival of circulating chronic lymphocytic leukemia cells ${ }^{[7]}$. Similarly, the binding of proMMP-2 or proMMP-9 to the integrins $\alpha$ $\mathrm{L} \beta 2$ and $\alpha \mathrm{M} \beta 2$ induces the migration of human AML cell lines ${ }^{[72]}$. Although AML cells from the majority of patients (at diagnosis or relapse) express chains of integrins and CD44 ${ }^{[73]}$, the potential roles of proMMP-2/9 in AML cell survival remain to be shown. Alternatively, HF might induce two simultaneous but distinct events (apoptosis and secretion inhibition) in AML cells. Due to its physicochemical properties, HF is easily incorporated into the membrane lipid bilayer, where it can function as a protonophore ${ }^{[74]}$. Lipid rafts modulate Akt/BAD signaling in cancer cells ${ }^{[75,76]}$ and regulate exocytosis/endocytosis pathways ${ }^{[77-80]}$. Whether HF disrupts lipid rafts in AML cells, which in turn simultaneously lead to cell apoptosis (through activation of Akt1/BAD) and blockade of secretion of MMP-2/9 and VEGF-A (through exocytosis inhibition) remains to be established. In view of this possibility, HF could join the family of natural compounds (including quercetin, epigallo catechin-3-gallate, resveratrol, and genistein) that induce apoptosis of tumor cells and block cytokine secretion through alteration of lipid rafts ${ }^{[5,76,81-84]}$.

In conclusion, among the search for novel therapeutics for AML, there is a need for the development of drugs that block angiogenesis associated with the AML disease. The inhibition of VEGF-A and/or MMP-2/9 may provide a therapeutic benefit in AML. Antiangiogenic strategies have sought to target the MMPs' catalytic activity ${ }^{[85]}$. The failure of MMP inhibitors as cancer drugs in the clinic may be explained by their lack of selectivity towards MMPs (including MMP-2/9). New approaches are focusing on more selective MMP inhibitors that target motifs outside the active site (the "exosite") of individual MMPs; these newly designed inhibitors include peptides that block exosite-mediated cell surface interactions and functionblocking anti-MMP antibodies ${ }^{[85-87]}$ to target proMMP-9-mediated cell migration in vitro ${ }^{[88-90]}$. To date, no efficient therapy based on MMP inhibition has been made available for targeting angiogenesis in cancers including AML, and new strategies are currently developing MMP-responsive drug delivery vehicles ${ }^{[87]}$. Studies with various VEGF inhibitors are currently underway in a number of tumors ${ }^{[1,91,92]}$. Bevacizumab, a humanized monoclonal antibody, binds to all circulating forms of VEGF, and thus it prevents VEGF binding to VEGF receptors. In addition to bevacizumab, other drugs have been reported to inhibit the binding of VEGF to its receptors (aflibercept) or block the signaling pathway mediated by VEGF receptors (ramucirumab, pazopanib, and axitinib) ${ }^{[1,91]}$. Bevacizumab treatment of AML patients with refractory/relapsing disease reduced VEGF expression at the level of BM but failed to show any significant clinical antileukemic activity ${ }^{[3]}$. Other clinical trials incorporating antibodies against VEGF or VEGF receptors-2 have not produced results supporting a significant clinical benefit ${ }^{[36]}$. These inhibitors share toxicity and other side effects ${ }^{[1,9,9,2]}$. Therefore, the development of new efficient antiangiogenic therapies is necessary. Utilization of natural compounds can be an alternative and/or an additional possibility to inhibit tumor development and associated angiogenesis ${ }^{[75,76,82-84]}$. By blocking in vitro the proliferation of primary blood endothelial cells, and reducing tumor vascularization and tumor-induced lymphangiogenesis in rat $\operatorname{model}^{[30,32,93]}$, HF could already be qualified as a putative antiangiogenic agent. Pharmacokinetics studies in 
humans have demonstrated oral bioavailability of $\mathrm{HF}^{[94]}$. However, two aspects limit the pharmacological use of purified HF, which concern: (1) its poor solubility and instability ${ }^{[30,95]}$; and (2) its interference with other therapeutic drugs via activation of liver CYP450 enzymes involved in the metabolism of pharmaceutical drugs (notably, CYP3A4) ${ }^{[94,96,97]}$. Oral administration by healthy volunteers of SJW extracts (300-2700 mg containing 14.8-70 mg of HF) results in the detection of 0.15-1.45 $\mu \mathrm{g} / \mathrm{mL}(0.28-2.68 \mu \mathrm{M}) \mathrm{HF}$ concentrations in blood $3 \mathrm{~h}$ after absorption ${ }^{[94,98-100]}$. An SJW treatment period of 12.5-21 days using high HF extracts (> $27 \mathrm{mg}$ /day) demonstrates a significant CYP3A induction ${ }^{[97]}$. Altogether, these data strongly suggest that the maximal concentration of HF in blood should not exceed $0.3 \mu \mathrm{g} / \mathrm{mL}(0.56 \mu \mathrm{M})$ to reduce the frequency of drug interactions. With regard to our data obtained in vitro, it remains to examine whether or not apoptosis and inhibition of secretion of AML cells in vivo can be triggered by a such low dose of HF. In the last years, various chemical derivatives of HF have been developed with improved stability and solubility, in the hope of removing HF drug metabolism stimulatory activities without affecting its antitumor properties. Thus, HF-DCHA, tetrahydro-HF-DCHA, octahydro-HF-DCHA, and O-(carboxy methyl)-HF have been shown to retain the antitumor and antiangiogenic properties of HF without inducing toxicity in laboratory animals ${ }^{[28,68,101,102]}$. Whether these HF derivatives retain the antileukemic properties of parental HF in vitro in AML primary cells and in experimental animals should be established. In parallel, the effects of these analogs on CYP3A activity have yet to be evaluated on healthy volunteers. Ongoing therapeutic strategies involve encapsulation of HF into polymeric nanoparticles for overcoming hurdles that hamper the bioactivity and bioavailability of the drug ${ }^{[103-106]}$. In conclusion, although further studies are undoubtedly required, all these data highlight that HF and its derivatives deserve further study to evaluate them in association with chemotherapy in the treatment of AML.

\section{DECLARATIONS}

\section{Acknowledgments}

The authors thank Fanny Fava (Hôpital Saint-Antoine, Paris, France) for her expert technical assistance. This work is dedicated to Jean-Pierre Kolb, a pionner in the research on antitumoral activity of HF in CLL.

\section{Authors' contributions}

Conceptualization: Merhi F, Bauvois B

Formal analysis: Merhi F, Tang R, Bauvois B

Investigation: Merhi F, Bauvois B

Methodology: Tang R, Merhi F, Bauvois B

Resources: Legrand O

Writing, review and editing: Merhi F, Tang R, Legrand O, Nguyen-Khac F, Susin SA, Bauvois B

All authors have read and agreed to the published version of the manuscript.

\section{Availability of data and materials}

Not applicable.

\section{Financial support and sponsorship}

This work was supported by the French National Institute of Health and Medical Research (INSERM). This research received no external funding.

\section{Conflicts of interest}

All authors declared that there are no conflicts of interest. 


\section{Ethical approval and consent to participate}

In line with the ethical tenets of the Declaration of Helsinki, all the patients diagnosed with AML provided their written and informed consent to participation in the study. Ethics approval was given by the independent ethics committees at Saint-Antoine Hospital (Paris, France) and the French National Institute of Cancer ("Tumorothèque Hématologie" Paris-Saint-Antoine Hospital COHO0203 INCA 2007). Control blood samples were collected from healthy, fully anonymized donors (no special written informed consent) in accordance with the institutional review boards of the Etablissement Français du Sang (Hôtel-Dieu Hospital, Paris, France) and the Institut National de la Santé et de la Recherche Médicale, Paris, France.

\section{Consent for publication}

Not applicable.

\section{Copyright}

(c) The Author(s) 2021.

\section{REFERENCES}

1. Testa U, Pelosi E, Castelli G. Endothelial progenitors in the tumor microenvironment. Adv Exp Med Biol 2020;1263:85-115. DOI PubMed

2. Ribatti D, Scavelli C, Roccaro AM, Crivellato E, Nico B, Vacca A. Hematopoietic cancer and angiogenesis. Stem Cells Dev 2004;13:484-95. DOI PubMed

3. Haouas H. Angiogenesis and acute myeloid leukemia. Hematology 2014;19:311-23. DOI PubMed

4. Najafabadi M, Shamsasenjan K, Akbarzadehalaleh P. Angiogenesis status in patients with acute myeloid leukemia: from diagnosis to post-hematopoietic stem cell transplantation. Int J Organ Transplant Med 2017;8:57-67. PubMed PMC

5. Bertolini F, Mancuso P, Gobbi A, Pruneri G. The thin red line: angiogenesis in normal and malignant hematopoiesis. Exp Hematol 2000;28:993-1000. DOI PubMed

6. Moehler TM, Neben K, Ho AD, Goldschmidt H. Angiogenesis in hematologic malignancies. Ann Hematol 2001;80:695-705. DOI PubMed

7. Rajkumar SV, Mesa RA, Tefferi A. A review of angiogenesis and anti-angiogenic therapy in hematologic malignancies. $J$ Hematother Stem Cell Res 2002;11:33-47. DOI PubMed

8. Bauvois B. New facets of matrix metalloproteinases MMP-2 and MMP-9 as cell surface transducers: outside-in signaling and relationship to tumor progression. Biochim Biophys Acta-Reviews on Cancer 2012;1825:29-36. DOI PubMed

9. Moss LA, Jensen-Taubman S, Stetler-Stevenson WG. Matrix metalloproteinases: changing roles in tumor progression and metastasis. Am J Pathol 2012;181:1895-9. DOI PubMed PMC

10. Cabral-Pacheco GA, Garza-Veloz I, Castruita-De la Rosa C, et al. The roles of matrix metalloproteinases and their inhibitors in human diseases. Int J Mol Sci 2020:21. DOI PubMed PMC

11. Murphy G, Nagase H. Localizing matrix metalloproteinase activities in the pericellular environment. Febs J 2010;278:2-15. DOI PubMed PMC

12. Klein T, Bischoff R. Physiology and pathophysiology of matrix metalloproteases. Amino Acids 2011;41:271-90. DOI PubMed PMC

13. Chen Q, Jin M, Yang F, Zhu J, Xiao Q, Zhang L. Matrix metalloproteinases: inflammatory regulators of cell behaviors in vascular formation and remodeling. Mediators Inflamm 2013;2013:928315. DOI PubMed PMC

14. Kessenbrock K, Plaks V, Werb Z. Matrix metalloproteinases: regulators of the tumor microenvironment. Cell 2010;141:52-67. DOI PubMed PMC

15. Medina MA, Martínez-Poveda B, Amores-Sánchez MI, Quesada AR. Hyperforin: more than an antidepressant bioactive compound? Life Sci 2006;79:105-11. DOI PubMed

16. McGrowder DA, Miller FG, Nwokocha CR, et al. Medicinal herbs used in traditional management of breast cancer: mechanisms of action. Medicines (Basel) 2020;7:47. DOI PubMed PMC

17. Varghese R, Dalvi YB. Natural products as anticancer agents. Curr Drug Targets 2020. DOI PubMed

18. Park SH, Kim M, Lee S, Jung W, Kim B. Therapeutic potential of natural products in treatment of cervical cancer: a review. Nutrients 2021;13:154. DOI PubMed PMC

19. Quiney C, Billard C, Salanoubat C, Fourneron JD, Kolb JP. Hyperforin, a new lead compound against the progression of cancer and leukemia? Leukemia 2006;20:1519-25. DOI PubMed

20. Borrelli F, Izzo AA. Herb-drug interactions with St John's wort (Hypericum perforatum): an update on clinical observations. Aaps $J$ 2009;11:710-27. DOI PubMed PMC

21. Feisst C, Pergola C, Rakonjac M, et al. Hyperforin is a novel type of 5-lipoxygenase inhibitor with high efficacy in vivo. Cell Mol Life Sci 2009;66:2759-71. DOI PubMed

22. Menegazzi M, Masiello P, Novelli M. Anti-tumor activity of hypericum perforatum L. and hyperforin through modulation of 
inflammatory signaling, ROS generation and proton dynamics. Antioxidants (Basel) 2020;10:18. DOI PubMed PMC

23. Hostanska K, Reichling J, Bommer S, Weber M, Saller R. Hyperforin a constituent of St John's wort (Hypericum perforatum L.) extract induces apoptosis by triggering activation of caspases and with hypericin synergistically exerts cytotoxicity towards human malignant cell lines. Eur J Pharm Biopharm 2003;56:121-32. DOI PubMed

24. Quiney C, Billard C, Faussat AM, et al. Pro-apoptotic properties of hyperforin in leukemic cells from patients with B-cell chronic lymphocytic leukemia. Leukemia 2006;20:491-7. DOI PubMed

25. Liu JY, Liu Z, Wang DM, et al. Induction of apoptosis in K562 cells by dicyclohexylammonium salt of hyperforin through a mitochondrial-related pathway. Chem Biol Interact 2011;190:91-101. DOI PubMed

26. Merhi F, Tang R, Piedfer M, et al. Hyperforin inhibits Akt1 kinase activity and promotes caspase-mediated apoptosis involving Bad and Noxa activation in human myeloid tumor cells. PLoS One 2011;6:e25963. DOI PubMed PMC

27. Liu YC, Lin KH, Hsieh JH, et al. Hyperforin Induces apoptosis through extrinsic/intrinsic pathways and inhibits NF-KB-modulated survival and invasion potential in bladder cancer. In Vivo 2019;33:1865-77. DOI PubMed PMC

28. Billard C, Merhi F, Bauvois B. Mechanistic insights into the antileukemic activity of hyperforin. Curr Cancer Drug Targets 2013;13:1-10. PubMed

29. Lorusso G, Vannini N, Sogno I, et al. Mechanisms of Hyperforin as an anti-angiogenic angioprevention agent. Eur J Cancer 2009;45:1474-84. DOI PubMed

30. Rothley M, Schmid A, Thiele W, et al. Hyperforin and aristoforin inhibit lymphatic endothelial cell proliferation in vitro and suppress tumor-induced lymphangiogenesis in vivo. Int J Cancer 2009;125:34-42. DOI PubMed

31. Dell'Aica I, Caniato R, Biggin S, Garbisa S. Matrix proteases, green tea, and St. John's wort: biomedical research catches up with folk medicine. Clin Chim Acta 2007;381:69-77. DOI PubMed

32. Quiney C, Billard C, Mirshahi P, Fourneron JD, Kolb JP. Hyperforin inhibits MMP-9 secretion by B-CLL cells and microtubule formation by endothelial cells. Leukemia 2006;20:583-9. DOI PubMed

33. Allegra A, Tonacci A, Spagnolo EV, Musolino C, Gangemi S. Antiproliferative effects of St. John's Wort, its derivatives, and other hypericum species in hematologic malignancies. Int J Mol Sci 2020:22. DOI PubMed PMC

34. Swords R, Freeman C, Giles F. Targeting the FMS-like tyrosine kinase 3 in acute myeloid leukemia. Leukemia 2012;26:2176-85. DOI PubMed

35. Rodriguez-Ariza A, Lopez-Pedrera C, Aranda E, Barbarroja N. VEGF targeted therapy in acute myeloid leukemia. Crit Rev Oncol Hematol 2011;80:241-56. DOI PubMed

36. Nair R, Salinas-Illarena A, Baldauf HM. New strategies to treat AML: novel insights into AML survival pathways and combination therapies. Leukemia 2021;35:299-311. DOI PubMed

37. Cucchi DGJ, Polak TB, Ossenkoppele GJ, et al. Two decades of targeted therapies in acute myeloid leukemia. Leukemia 2021;35:651-60. DOI PubMed

38. Estey E. New treatments for acute myeloid leukemia: how much has changed? Leukemia 2021;35:45-6. DOI PubMed

39. Hussong JW, Rodgers GM, Shami PJ. Evidence of increased angiogenesis in patients with acute myeloid leukemia. Blood 2000;95:309-13. PubMed

40. Padró T, Bieker R, Ruiz S, et al. Overexpression of vascular endothelial growth factor (VEGF) and its cellular receptor KDR (VEGFR-2) in the bone marrow of patients with acute myeloid leukemia. Leukemia 2002;16:1302-10. DOI PubMed

41. Fiedler W, Graeven U, Ergün S, et al. Vascular endothelial growth factor, a possible paracrine growth factor in human acute myeloid leukemia. Blood 1997;89:1870-5. PubMed

42. Ghannadan M, Wimazal F, Simonitsch I, et al. Immunohistochemical detection of VEGF in the bone marrow of patients with acute myeloid leukemia. Correlation between VEGF expression and the FAB category. Am J Clin Pathol 2003;119:663-71. DOI PubMed

43. Bont ES, Fidler V, Meeuwsen T, Scherpen F, Hählen K, Kamps WA. Vascular endothelial growth factor secretion is an independent prognostic factor for relapse-free survival in pediatric acute myeloid leukemia patients. Clin Cancer Res 2002;8:2856-61. PubMed

44. Aguayo A, Kantarjian H, Manshouri T, et al. Angiogenesis in acute and chronic leukemias and myelodysplastic syndromes. Blood 2000;96:2240-5. PubMed

45. Janowska-Wieczorek A, Marquez LA, et al. Expression of matrix metalloproteinases (MMP-2 and -9) and tissue inhibitors of metalloproteinases (TIMP-1 and -2) in acute myelogenous leukaemia blasts: comparison with normal bone marrow cells. $\mathrm{Br} J$ Haematol 1999; 105:402-11. PubMed

46. Ries C, Loher F, Zang C, Ismair MG, Petrides PE. Matrix metalloproteinase production by bone marrow mononuclear cells from normal individuals and patients with acute and chronic myeloid leukemia or myelodysplastic syndromes. Clin Cancer Res 1999;5:1115-24. PubMed

47. Chaudhary AK, Chaudhary S, Ghosh K, Shanmukaiah C, Nadkarni AH. Secretion and expression of matrix metalloproteinase-2 and 9 from bone marrow mononuclear cells in myelodysplastic syndrome and acute myeloid leukemia. Asian Pac J Cancer Prev 2016;17:1519-29. DOI PubMed

48. Reikvam H, Hatfield KJ, Oyan AM, Kalland KH, Kittang AO, Bruserud O. Primary human acute myelogenous leukemia cells release matrix metalloproteases and their inhibitors: release profile and pharmacological modulation. Eur J Haematol 2009;84:239-51. DOI PubMed

49. King ME, Rowe JM. Recent developments in acute myelogenous leukemia therapy. Oncologist 2007;12 Suppl 2:14-21. DOI PubMed

50. Bauvois B, Nguyen J, Tang R, Billard C, Kolb JP. Types I and II interferons upregulate the costimulatory CD 80 molecule in monocytes via interferon regulatory factor-1. Biochem Pharmacol 2009;78:514-22. DOI PubMed 
51. Bouchet S, Tang R, Fava F, Legrand O, Bauvois B. The CNGRC-GG-D(KLAKLAK)2 peptide induces a caspase-independent, Ca2+dependent death in human leukemic myeloid cells by targeting surface aminopeptidase N/CD13. Oncotarget 2016;7:19445-67. DOI PubMed PMC

52. Bauvois B, Dumont J, Mathiot C, Kolb JP. Production of matrix metalloproteinase-9 in early stage B-CLL: suppression by interferons. Leukemia 2002;16:791-8. DOI PubMed

53. Bauvois B, Pramil E, Jondreville L, et al. Relation of neutrophil gelatinase-associated lipocalin overexpression to the resistance to apoptosis of tumor B cells in chronic lymphocytic leukemia. Cancers (Basel) 2020;12:2124. DOI PubMed PMC

54. Trocme C, Gaudin P, Berthier S, Barro C, Zaoui P, Morel F. Human B lymphocytes synthesize the 92-kDa gelatinase, matrix metalloproteinase-9. J Biol Chem 1998;273:20677-84. DOI PubMed

55. Munaut C, Noel A, Hougrand O, Foidart JM, Boniver J, Deprez M. Vascular endothelial growth factor expression correlates with matrix metalloproteinases MT1-MMP, MMP-2 and MMP-9 in human glioblastomas. Int J Cancer 2003;106:848-55. DOI PubMed

56. Bauvois B, Pramil E, Jondreville L, Quiney C, Nguyen-Khac F, Susin SA. Activation of interferon signaling in chronic lymphocytic leukemia cells contributes to apoptosis resistance via a JAK-Src/STAT3/Mcl-1 signaling pathway. Biomedicines 2021;9:188. DOI PubMed PMC

57. Wang ZB, Liu YQ, Cui YF. Pathways to caspase activation. Cell Biol Int 2005;29:489-96. DOI PubMed

58. Paupert J, Mansat-De Mas V, Demur C, Salles B, Muller C. Cell-surface MMP-9 regulates the invasive capacity of leukemia blast cells with monocytic features. Cell Cycle 2008;7:1047-53. DOI PubMed

59. Toth M, Gervasi DC, Fridman R. Phorbol ester-induced cell surface association of matrix metalloproteinase-9 in human MCF10A breast epithelial cells. Cancer Res 1997;57:3159-67. PubMed

60. Ogata Y, Enghild JJ, Nagase H. Matrix metalloproteinase 3 (stromelysin) activates the precursor for the human matrix metalloproteinase 9. J Biol Chem 1992;267:3581-4. PubMed

61. Knäuper V, Smith B, López-Otin C, Murphy G. Activation of progelatinase B (proMMP-9) by active collagenase-3 (MMP-13). Eur J Biochem 1997;248:369-73. DOI PubMed

62. Aggarwal BB, Kunnumakkara AB, Harikumar KB, et al. Signal transducer and activator of transcription-3, inflammation, and cancer: how intimate is the relationship? Ann N Y Acad Sci 2009;1171:59-76. DOI PubMed PMC

63. Tolomeo M, Cascio A. The multifaced role of STAT3 in cancer and its implication for anticancer therapy. Int J Mol Sci 2021;22:603. DOI PubMed PMC

64. Vandooren J, Van den Steen PE, Opdenakker G. Biochemistry and molecular biology of gelatinase B or matrix metalloproteinase-9 (MMP-9): the next decade. Crit Rev Biochem Mol Biol 2013;48:222-72. DOI PubMed

65. Choueiri TK, Kaelin WG, Jr. Targeting the HIF2-VEGF axis in renal cell carcinoma. Nat Med 2020;26:1519-30. DOI PubMed

66. Aref S, Osman E, Mansy S, et al. Prognostic relevance of circulating matrix metalloproteinase-2 in acute myeloid leukaemia patients. Hematol Oncol 2007;25:121-6. DOI PubMed

67. Martelli AM, Nyåkern M, Tabellini G, et al. Phosphoinositide 3-kinase/Akt signaling pathway and its therapeutical implications for human acute myeloid leukemia. Leukemia 2006;20:911-28. DOI PubMed

68. Dona M, Dell'Aica I, Pezzato E, et al. Hyperforin inhibits cancer invasion and metastasis. Cancer Res 2004;64:6225-32. DOI PubMed

69. Kampen KR, Ter Elst A, de Bont ES. Vascular endothelial growth factor signaling in acute myeloid leukemia. Cell Mol Life Sci 2013;70:1307-17. DOI PubMed

70. Wiszniak S, Schwarz Q. Exploring the intracrine functions of VEGF-A. Biomolecules 2021;11:128. DOI PubMed PMC

71. Redondo-Munoz J, Ugarte-Berzal E, Terol MJ, et al. Matrix metalloproteinase-9 promotes chronic lymphocytic leukemia b cell survival through its hemopexin domain. Cancer Cell 2010;17:160-72. DOI PubMed

72. Stefanidakis M, Karjalainen K, Jaalouk DE, et al. Role of leukemia cell invadosome in extramedullary infiltration. Blood 2009;114:3008-17. DOI PubMed PMC

73. Kortlepel K, Bendall LJ, Gottlieb DJ. Human acute myeloid leukaemia cells express adhesion proteins and bind to bone marrow fibroblast monolayers and extracellular matrix proteins. Leukemia 1993;7:1174-9. PubMed

74. Sell TS, Belkacemi T, Flockerzi V, Beck A. Protonophore properties of hyperforin are essential for its pharmacological activity. Sci Rep 2014;4:7500. DOI PubMed PMC

75. Mollinedo F, Gajate C. Lipid rafts as major platforms for signaling regulation in cancer. Adv Biol Regul 2015;57:130-46. DOI PubMed

76. George KS, Wu S. Lipid raft: a floating island of death or survival. Toxicol Appl Pharmacol 2012;259:311-9. DOI PubMed PMC

77. Nichols B. Caveosomes and endocytosis of lipid rafts. J Cell Sci 2003;116:4707-14. DOI PubMed

78. Salaün C, James DJ, Chamberlain LH. Lipid rafts and the regulation of exocytosis. Traffic 2004;5:255-64. DOI PubMed PMC

79. Hanzal-Bayer MF, Hancock JF. Lipid rafts and membrane traffic. FEBS Lett 2007;581:2098-104. DOI PubMed

80. Ouweneel AB, Thomas MJ, Sorci-Thomas MG. The ins and outs of lipid rafts: functions in intracellular cholesterol homeostasis, microparticles, and cell membranes. J Lipid Res 2020;61:676-86. DOI PubMed PMC

81. Dell'Agli M, Canavesi M, Galli G, Bellosta S. Dietary polyphenols and regulation of gelatinase expression and activity. Thromb Haemost 2005;93:751-60. DOI PubMed

82. Coleman DT, Bigelow R, Cardelli JA. Inhibition of fatty acid synthase by luteolin post-transcriptionally down-regulates c-Met expression independent of proteosomal/lysosomal degradation. Mol Cancer Ther 2009;8:214-24. DOI PubMed PMC

83. Duhon D, Bigelow RL, Coleman DT, et al. The polyphenol epigallocatechin-3-gallate affects lipid rafts to block activation of the cMet receptor in prostate cancer cells. Mol Carcinog 2010;49:739-49. DOI PubMed 
84. Mocanu MM, Ganea C, Georgescu L, et al. Epigallocatechin 3-O-gallate induces $67 \mathrm{kDa}$ laminin receptor-mediated cell death accompanied by downregulation of ErbB proteins and altered lipid raft clustering in mammary and epidermoid carcinoma cells. $J$ Nat Prod 2014;77:250-7. DOI PubMed

85. Overall CM, Kleifeld O. Towards third generation matrix metalloproteinase inhibitors for cancer therapy. Br J Cancer 2006;94:9416. DOI PubMed PMC

86. Sela-Passwell N, Rosenblum G, Shoham T, Sagi I. Structural and functional bases for allosteric control of MMP activities: can it pave the path for selective inhibition? Biochim Biophys Acta 2010;1803:29-38. DOI PubMed

87. Raeeszadeh-Sarmazdeh M, Do LD, Hritz BG. Metalloproteinases and their inhibitors: potential for the development of new therapeutics. Cells 2020;9:1313. DOI PubMed PMC

88. Bjorklund M, Heikkila P, Koivunen E. Peptide inhibition of catalytic and noncatalytic activities of matrix metalloproteinase-9 blocks tumor cell migration and invasion. J Biol Chem 2004;279:29589-97. DOI PubMed

89. Mantuano E, Inoue G, Li X, et al. The hemopexin domain of matrix metalloproteinase-9 activates cell signaling and promotes migration of schwann cells by binding to low-density lipoprotein receptor-related protein. J Neurosci 2008;28:11571-82. DOI PubMed PMC

90. Dufour A, Zucker S, Sampson NS, Kuscu C, Cao J. Role of matrix metalloproteinase-9 dimers in cell migration: design of inhibitory peptides. J Biol Chem 2010;285:35944-56. DOI PubMed PMC

91. Ollauri-Ibáñez C, Astigarraga I. Use of antiangiogenic therapies in pediatric solid tumors. Cancers (Basel) 2021:13. DOI PubMed PMC

92. Jayson GC, Kerbel R, Ellis LM, Harris AL. Antiangiogenic therapy in oncology: current status and future directions. Lancet 2016;388:518-29. DOI PubMed

93. Schempp CM, Kiss J, Kirkin V, et al. Hyperforin acts as an angiogenesis inhibitor. Planta Med 2005;71:999-1004. DOI PubMed

94. Wurglics M, Schubert-Zsilavecz M. Hypericum perforatum: a 'modern' herbal antidepressant: pharmacokinetics of active ingredients. Clin Pharmacokinet 2006;45:449-68. DOI PubMed

95. Ang CY, Hu L, Heinze TM, et al. Instability of St. John's wort (Hypericum perforatum L.) and degradation of hyperforin in aqueous solutions and functional beverage. J Agric Food Chem 2004;52:6156-64. DOI PubMed

96. Chen Y, Ferguson SS, Negishi M, Goldstein JA. Induction of human CYP2C9 by rifampicin, hyperforin, and phenobarbital is mediated by the pregnane X receptor. J Pharmacol Exp Ther 2004;308:495-501. DOI PubMed

97. Whitten DL, Myers SP, Hawrelak JA, Wohlmuth H. The effect of St John's wort extracts on CYP3A: a systematic review of prospective clinical trials. Br J Clin Pharmacol 2006;62:512-26. DOI PubMed PMC

98. Biber A, Fischer H, Romer A, Chatterjee SS. Oral bioavailability of hyperforin from hypericum extracts in rats and human volunteers. Pharmacopsychiatry 1998;31 Suppl 1:36-43. DOI PubMed

99. Schulz HU, Schurer M, Bassler D, Weiser D. Investigation of pharmacokinetic data of hypericin, pseudohypericin, hyperforin and the flavonoids quercetin and isorhamnetin revealed from single and multiple oral dose studies with a hypericum extract containing tablet in healthy male volunteers. Arzneimittelforschung 2005;55:561-8. DOI PubMed

100. Franklin M, Chi J, McGavin C, et al. Neuroendocrine evidence for dopaminergic actions of hypericum extract (LI 160) in healthy volunteers. Biol Psychiatry 1999;46:581-4. DOI PubMed

101. Gartner M, Muller T, Simon JC, Giannis A, Sleeman JP. Aristoforin, a novel stable derivative of hyperforin, is a potent anticancer agent. Chembiochem 2005;6:171-7. DOI PubMed

102. Martinez-Poveda B, Verotta L, Bombardelli E, Quesada AR, Medina MA. Tetrahydrohyperforin and octahydrohyperforin are two new potent inhibitors of angiogenesis. PLoS One 2010;5:e9558. DOI PubMed PMC

103. Chauvet S, Barras A, Boukherroub R, Bouron A. Lipid nanocapsules containing the non-ionic surfactant Solutol HS15 inhibit the transport of calcium through hyperforin-activated channels in neuronal cells. Neuropharmacology 2015;99:726-34. DOI PubMed

104. Nosratabadi R, Rastin M, Sankian M, Haghmorad D, Mahmoudi M. Hyperforin-loaded gold nanoparticle alleviates experimental autoimmune encephalomyelitis by suppressing Th1 and Th17 cells and upregulating regulatory T cells. Nanomedicine 2016;12:196171. DOI PubMed

105. Füller J, Kellner T, Gaid M, Beerhues L, Müller-Goymann CC. Stabilization of hyperforin dicyclohexylammonium salt with dissolved albumin and albumin nanoparticles for studying hyperforin effects on 2D cultivation of keratinocytes in vitro. Eur J Pharm Biopharm 2018;126:115-22. DOI PubMed

106. Traeger A, Voelker S, Shkodra-Pula B, et al. Improved bioactivity of the natural product 5-lipoxygenase inhibitor hyperforin by encapsulation into polymeric nanoparticles. Mol Pharm 2020;17:810-6. DOI PubMed 